Current Pharmaceutical Design. 2019; 25(6): 738-745.

doi: $10.2174 / 1381612825666190402105803$.

\title{
Depression and Treatment with Effective Herbs
}

\author{
Zohre Fathinezhad $^{1}$, Robert D.E Sewell ${ }^{2}$, \\ Zahra Lorigooini ${ }^{3}$, Mahmoud Rafieian-Kopaei ${ }^{3}{ }^{*}$
}

\footnotetext{
${ }^{1}$ Department of Biochemistry, Faculty of Biological Sciences, Tarbiat Modares University, Tehran, Iran.

${ }^{2}$ Cardiff School of Pharmacy and Pharmaceutical Sciences, Cardiff University, Cardiff, CF10 3NB. Wales, U.K.

${ }^{3}$ Medical Plants Research Center, Basic Health Sciences Institute, Shahrekord University of Medical Sciences, Shahrekord, Iran.
}

* Correspondence to: rafieian@yahoo.com 
Abstract

Depression is a common psychiatric disease and one of the main causes of disability worldwide. In spite of certain developments in this field, chemical and synthetic drugs used for the treatment of depression may disrupt the treatment process due to numerous side effects and high cost. Today, the goal of using a potential method for treating depression involves the use of medicinal and phytochemical plants, which have many therapeutic benefits. Studies have shown that medicinal plants affect the nervous system and exert antidepressant effects in various ways, including synaptic regulation of serotonin, noradrenaline and dopamine, and inflammatory mediators. In this study, depression as well as the factors and mechanisms involved in its development are first addressed, and then medicinal plants effective in the treatment of depression along with their mechanisms of actions are reported

Keywords: Depression, biomarkers, bio-factors, mechanism, medicinal plants. 


\section{INTRODUCTION}

Depression is one of the five most commonly diagnosed diseases across the world and is expected to be the second leading cause of disability worldwide by 2020 [1]. The global prevalence of major depression is $4.7 \%$. This means that out of every 20 people, one individual is affected by depression. The prevalence of depression in the elderly people and in women is higher than other populations [2]. The depression prevalence in women is $10-25 \%$ and in men is 5-12\% [3], i.e., the prevalence of depression in women is about twice that of men. According to the definition of the American Psychiatric Association, depression is a heterogeneous disorder that is often associated with physiological, behavioral and psychological symptoms [4]. Depression causes mood changes, difficulty in thinking, and loss of interest as well as physical problems such as headache, sleep disorders, loss of energy and sexual problems $[5,6]$. The causes of the disease include genetic factors, chemical changes in the brain, psychosocial issues, psychodynamic factors, changes in hormonal levels, various physical illnesses, medications and malnutrition, and even diet. Recently, internal stressors such as changes in the serum levels of cholesterol, triglycerides, glucose, and coagulation factors have been reported to be associated with depression [7]. Dysfunction of brain monoamine receptors, monoamine secretion, general dysfunction of the monoamine system and dysfunction of the second messenger system are the main focus of pathophysiological hypotheses regarding depression $[8,9,10]$. A number of drugs are available for the treatment of depression, but clinical evaluation of these drugs has shown recurrence of the disease and certain side effects in addition to drug interactions. Tricyclic antidepressants can cause certain complications, including dry mouth, distress, constipation, dizziness, thirst, blurred vision, high blood pressure, inability to drive, and sexual dysfunction $[5,11,12]$. Monoamine oxidase inhibitors (MAOIs) can cause relief or behavioral stimulation and an increase in the risk of developing postural hypotension [3]. Newer antidepressants usually have fewer or different side effects and a lower risk of toxicity than older tricyclic inhibitors and MAO inhibitors. Although drug therapy is widely prescribed for depression by doctors, less than half of the patients treated with antidepressants respond to these drugs [13]. Some patients recover partially or indirectly, and some patients are resistant to pharmacotherapy. It is therefore emphasized that there is a need to seek out new antidepressant classes. Due to the adverse effects of synthetic and chemical drugs, the use of medicinal plants, as an alternative treatment, may be relatively better, as many studies with different models have reported the positive pharmacological effects of plants in the treatment of depression [3]. In this study, depression, as well as the factors and mechanisms involved in its development, will be first addressed, and then medicinal plants and their active ingredients effective in treating depression along with their mechanisms of actions will be reported. 


\subsection{Biomarkers and Bio-factors Involved Depression}

Various factors are involved in the development of depression (Fig. 1). Focus on the pathogenesis of depression in recent years has mainly targeted monoamine neurotransmitter disorders, decreased monoamine production, or secondary messenger system dysfunction [14]. Monoamine neurotransmitters such as serotonin (5-HT), noradrenaline, and dopamine play an important role in mediating depressive behaviors. Depression is caused by decreased function of these neurotransmitters. Monoamine oxidase-A (MAO-A) activity is one of the indicators of predisposition to mental disorders [15]. This enzyme is one of the key enzymes that are involved in the metabolism of neurotransmitters. In addition, the hypothalamic-pituitaryadrenal (HPA) axis function is impaired in patients with depression. The HPA axis is regulated by corticotropin-releasing factor (CRF). This physiological regulator plays a major role in mediating behavioral, neuroendocrine and autonomic responses to environmental stimuli. Increased CRF and hyperactivity of the HPA axis are indicative of depression [16, 17]. The levels of CRF, cortisol, and adrenocorticotropic hormone (ACTH) also increase in depressive patients [18]. There is also a relationship between adenylyl cyclase activity and major depression. Adenylyl cyclase regulates the physiological effect of drugs and hormones by producing cAMP [18]. Adenylyl cyclase activity is controlled by serotonergic receptors. In clinical trials, it has been observed that the activity of this enzyme is lower in people with depression than in those without depression [19]. One of the other factors that are involved in the pathogenesis of depression is oxidative stress. In fact, the imbalance between the production of reactive oxygen species (ROS) and the antioxidant defence system may cause or exacerbate depression [20]. Several degrees of oxidative damage and a decrease in antioxidant inhibitory enzymes have been reported in people with depression. As a result, antioxidant compounds such as acetylcysteine decrease the symptoms of depression in affected individuals [21]. Some inflammatory mediators have been reported to be involved in the development of depression in both patients and animal models, including tumor necrosis factor-alpha (TNF $\alpha)$ and interleukin 1 beta (IL-1 $\beta$ ). The association between inflammation and depression has been observed in people with hepatitis $\mathrm{C}$ or cancer who are under TNF $\gamma$ or IL2 based immunotherapy [22]. It has also been observed that changes in the levels of tyrosine, tryptophan and phenylalanine, which indicate an amino acid metabolism disorder, are associated with depression [23]. Phenylalanine is an essential amino acid and precursor of tyrosine from which monoamine neurotransmitters such as serotonin, norepinephrine and epinephrine are derived. Tryptophan is also an essential amino acid and the precursor of serotonin. Therefore, changes in the amount of this type of amino acids are associated with depression. Impaired energy metabolism and gut microflora have also been associated with depression. In fact, depression is associated with significant changes in the biomarkers of gut microflora. Impairment in energy conversion and Krebs' cycle (tricarboxylic acid cycle) due to changes in creatinine and succinic acid disrupts energy metabolism and causes fatigue, which is one of the symptoms of the disease. The microflora-induced changes in hippuric acid and 3-indole acetic acid due to depression suggest an association between depression and gut microflora metabolism [24]. Glutamic acid and gamma-aminobutyric acid (GABA) act as 
excitatory and inhibitory neurotransmitters in the mammalian brain and play an important role in mediating anxiety and depressive behaviors. Therefore, the changes in these neurotransmitters are also associated with depression [24]. In addition, Glutamate transmission inhibitors can have antidepressant effects [25].

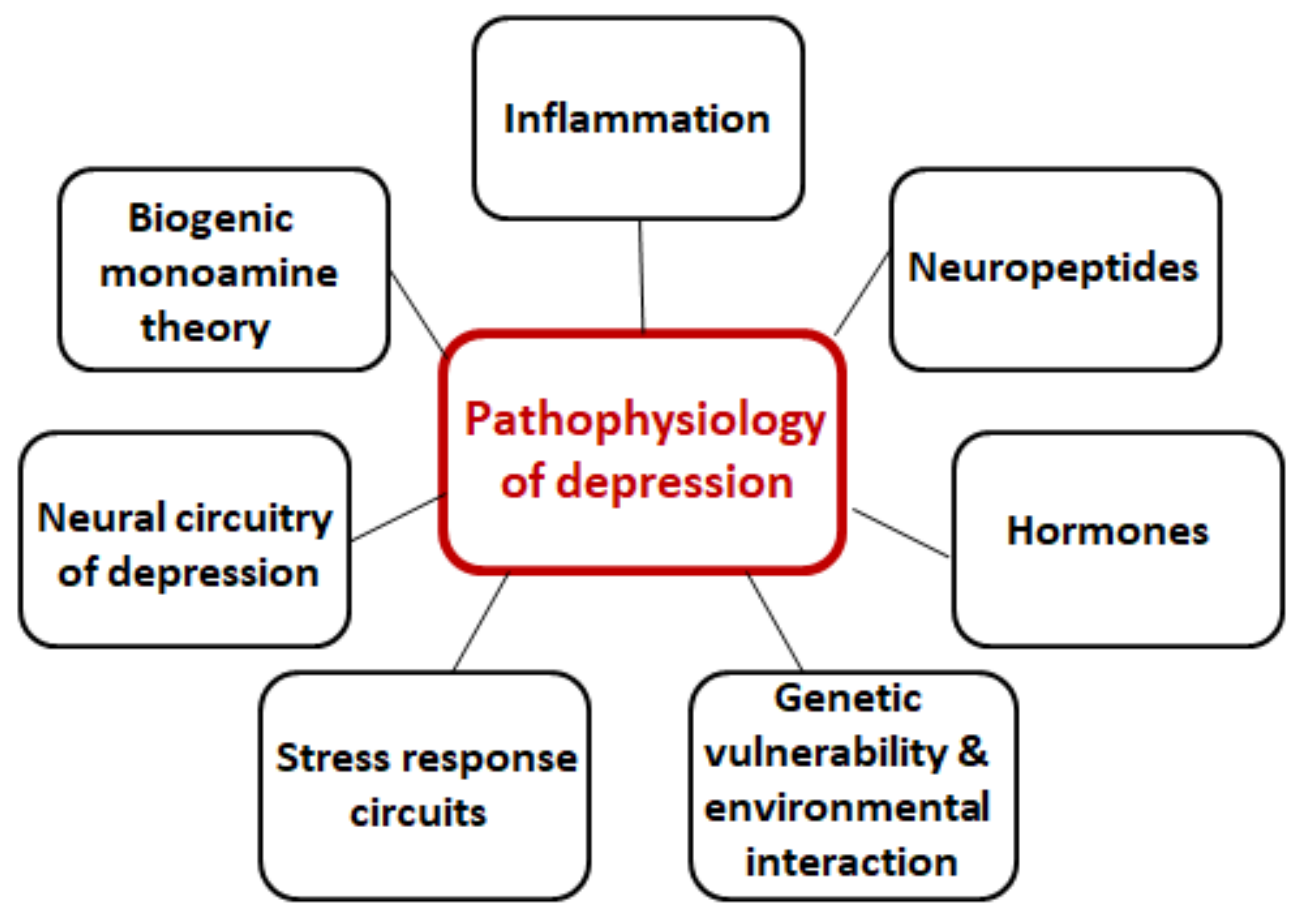

Fig. (1). The most important factors involved in depression [26].

\subsection{Pharmacotherapy and its mechanisms}

The development of the first antidepressant drugs, MOA inhibitors and tricyclic antidepressants in the 1950s and 1960s marked a substantial development in the treatment of depression [2]. The introduction of subsequent drugs such as selective serotonin reuptake inhibitors (SSRIs) and serotonin-norepinephrine reuptake inhibitors (SNRI) such as venlafaxine, has improved the therapeutic success against depression in the past decade as much as it was with previous drugs, but with higher tolerance and fewer side effects [2]. Recently, atypical antidepressants such as bupropion, nefazodone, and mirtazapine are available to treat depression. However, the rate of recovery and the risk of disease recurrence remain high. Therefore, agents with greater efficacy and less toxicity are needed [2]. Research has shown that antidepressants exhibit inhibitory effects on the expression of inflammatory cytokines such as TNF alpha and prostaglandin E2, and the production of ROS [27]. Finally, conventional antidepressant drugs play their role by increasing monoamine levels in the synaptic cleft through at least one of the following mechanisms (Fig. 2): 
1. Blocking pre-synaptic monoamine transporter increasing extracellular neurotransmitter.

2. Inhibiting MOA that destroys monoamine transmitters. Monoamine oxidase inhibitors (MAOIs) are the antidepressants that destroy the neurotransmitters serotonin, norepinephrine, and dopamine in the brain.

3. Binding to pre- or postsynaptic receptors that regulate monoamine release or its rate. It is suggested that antidepressants increase the concentration of extracellular monoamine. Depression may be caused by the lack of noradrenaline, 5-HT and dopamine in the brain at receptor sites. This argument is known as the monoamine hypothesis of depression [15]. Conventional antidepressants lead brain-derived neurotrophic factor (BDNF) toward acting as an effective antidepressant agent by increasing its level in the frontal lobe and especially the hippocampus. BDNF causes neuroplasticity that improves symptoms of depression [15].

The most common side effects of synthetic drugs are a rapid increase in the concentration of monoamine at the receptor site, which can increase anxiety and cause digestive and sexual problems [5], challenging the use of new antidepressant drugs due to late efficacy and numerous side effects. As a rich source of biologically active molecules, medicinal plants represent a promising source from which to develop new antidepressants.

\subsection{Effective Medicinal Plants on Depression}

Studies have shown that the desirable health effects of herbal drugs are largely due to their antioxidant properties and potential impact on cellular metabolism [28]. Medicinal plants can regulate neurotransmission by directly affecting receptors or the synthesis and distribution of neurotransmitters, or by regulating immunological processes [29]. Investigations by Rai et al [72] showed that the antidepressant effect of the active ingredients of medicinal plants was associated with neutralizing various stressors and returning monoamine receptor and neurotransmitter levels to normal and also by increasing the level of monoamine neurotransmitters in certain regions of the cortex [27, 72]. Medicinal plants and their active ingredients also produce therapeutic effects via interaction with serotonergic systems (5-HT3, 5HT2A, 5-HT1A), noradrenergic ( $\alpha 1$ and $\alpha 2$ receptors) and dopaminergic (D1 and D2) receptors [30]. Medicinal plants also regulate the activity of the HPA axis and reduce CRF, and adrenocorticotropin and corticosterone. Some plants remove the symptoms of depression by reducing oxidative stress and inflammatory mediators. The present section addresses the overall antidepressant activity of plants. 


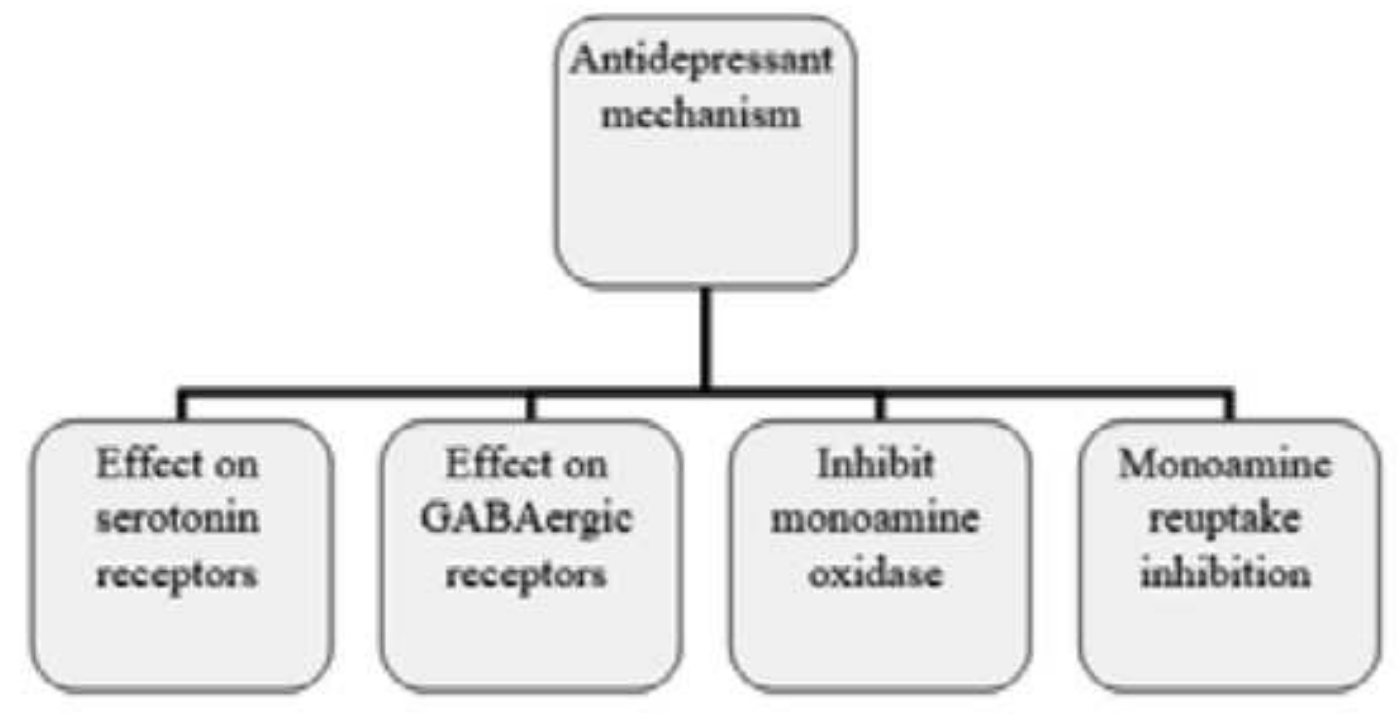

Fig. (2). Antidepressant mechanisms.

Plant-derived antidepressant phytochemicals are known to reduce the risk of certain severe disorders, including autoimmune and cardiovascular diseases, as well as neurodegenerative diseases [15]. Some herbal drugs have been approved by regulatory authorities for treating psychiatric disorders. For example, the Brazilian Health Regulatory Agency (Anvisa) has approved certain products obtained from Passiflora incarnata, Valeriana officinalis, Cimicifuga racemosa, and Piper methysticum for treating anxiety or depression. Similarly, the European Medicines Agency (EMA) has listed some plants including Hypericum perforatum L. (St. John's Wort), Melissa officinalis L. (Melissa leaf), and V. officinalis L. (Valerian Root) as being approved for the treatment of mental stress and mood disorders [31]. In these plants, well-known polyphenols such as curcumin, ferulic acid, proanthocyanidin, quercetin and resveratrol have shown potent anti-inflammatory and antioxidant properties. These phytochemicals have been frequently reported to produce neuropathic effects, which strongly indicates that they can improve symptoms of depression [15]. Table 1 shows some of the plants associated with depression.

\subsection{Toxicity of Medicinal Plants}

The use of medicinal plants and herbal medicines dates back in human history. Nowadays, about seventy percent of the population consume these plants for disease treatment and low toxicity although they can produce certain toxic effects [73]. Some plants are not inherently toxic, but the levels of some elements in them can be very high being sourced from environmental pollution. Fungal contamination in stored plants is a big problem, too. [74]. Although the washing process may remove toxic components, some elements such as lead and cadmium are not easily removed [75]. Most of the available medicinal plants and herbal products are not prepared industrially and do not carry the necessary information on their 
packaging. Moreover, they often have not been certified and validated by a recognized body, which can concern medical practitioners as well as consumers [75]. These plants may induce a variety of toxicities in different organs of the body. In this respect, the liver and kidney are very vulnerable to herbal toxicities [76-78]. Therefore, they should be used with caution, especially for their toxic effects on kidney and liver. It should be noted that medicinal plants might also be beneficial to liver and kidneys. There are many medicinal plants, which have been shown to protect kidney or liver, or both. These plants mostly have antioxidant activity and counteract the oxidative stress induced by free radicals [79-81].

Table 1. The most important herbal medicines effective on depression and their mechanisms.

\begin{tabular}{|c|c|c|c|c|c|c|c|}
\hline Name & Family & Model & Action mechanism(s) & $\begin{array}{l}\text { Main com- } \\
\text { pound(s) }\end{array}$ & $\begin{array}{c}\text { Place of } \\
\text { occurrence }\end{array}$ & $\begin{array}{c}\text { Type of used } \\
\text { extract }\end{array}$ & Reference \\
\hline $\begin{array}{l}\text { Epimedium } \\
\text { brevicornum }\end{array}$ & $\begin{array}{l}\text { Berberi- } \\
\text { daceae }\end{array}$ & CUMS & $\begin{array}{l}\text { Suppressing monoamine oxidase } \\
\text { A (MAO-A) and monoamine } \\
\text { oxidase B (MAO-B) enzymes } \\
\text { and reducing serum malondial- } \\
\text { dehyde (MDA) levels }\end{array}$ & $\begin{array}{c}\text { Icariin } \\
\text { (Flavonoid) }\end{array}$ & $\begin{array}{l}\text { Asia, China } \\
\text { and } \\
\text { Mediterranean } \\
\text { region }\end{array}$ & & {$[22,17,32]$} \\
\hline $\begin{array}{c}\text { Chrysactinia } \\
\text { mexicana }\end{array}$ & Asteraceae & & $\begin{array}{l}\text { NMDA receptor antagonist and } \\
\text { protecting neurons against exci- } \\
\text { totoxic effects of NMDA; } \\
\text { Increasing the division of stem } \\
\text { cells or neuronal precursors in } \\
\text { vivo and in vitro; } \\
\text { Binding to the benzodiazepine } \\
\text { binding site of GABA-A recep- } \\
\text { tors and inducing pharmacologi- } \\
\text { cal properties }\end{array}$ & $\begin{array}{l}\text { Phenylpro- } \\
\text { panoids in- } \\
\text { cluding caffeic } \\
\text { acid, coumaric } \\
\text { acid and } \\
\text { ferulic acid }\end{array}$ & $\begin{array}{l}\text { North Amer- } \\
\text { ica, Mexico, } \\
\text { and some } \\
\text { South Ameri- } \\
\text { can countries }\end{array}$ & & $\begin{array}{c}{[33,34,35,} \\
36,37]\end{array}$ \\
\hline $\begin{array}{c}\text { Chamaemelum } \\
\text { nobile }\end{array}$ & $\begin{array}{c}\text { Asteraceae/ } \\
\text { Composit }\end{array}$ & & $\begin{array}{l}\text { Apigenin present in the plant } \\
\text { acts as a ligand of the benzodi- } \\
\text { azepine receptor } \\
\text { Quercetin inhibits monoamine } \\
\text { oxidase }\end{array}$ & $\begin{array}{l}\text { The flavonoids } \\
\text { apigenin, } \\
\text { quercetin, } \\
\text { luteolin and } \\
\text { terpenoid } \\
\text { alpha, } \\
\text { Bisabolol }\end{array}$ & $\begin{array}{l}\text { Different } \\
\text { Mediterranean } \\
\text { regions, } \\
\text { Europe, and } \\
\text { temperate } \\
\text { regions of } \\
\text { Asia and the } \\
\text { USA }\end{array}$ & & {$[38,39]$} \\
\hline $\begin{array}{l}\text { Magnolia } \\
\text { grandiflora }\end{array}$ & Magnoliacea & $\begin{array}{l}\text { FST, TST, } \\
\text { CUMS }\end{array}$ & $\begin{array}{l}\text { Producing effect on the seroton- } \\
\text { ergic system; } \\
\text { Regulating 5-HT, 5-HIAA, } \\
\text { corticosterone and adenyly1 } \\
\text { cyclase. }\end{array}$ & $\begin{array}{c}\text { Magnolol and } \\
\text { honokiol }\end{array}$ & $\begin{array}{l}\text { Japan and } \\
\text { China }\end{array}$ & Aqueous & {$[40,41,32]$} \\
\hline
\end{tabular}




\begin{tabular}{|c|c|c|c|c|c|c|c|}
\hline $\begin{array}{l}\text { Hypericum } \\
\text { perforatum }\end{array}$ & Hypericaceae & $\begin{array}{c}\text { Escape } \\
\text { deficit } \\
\text { models, } \\
\text { Anhedonia } \\
\text { test, FST }\end{array}$ & $\begin{array}{l}\text { A weak inhibitor of MOA; } \\
\text { Downregulating the beta } \\
\text { adrenergic receptors and upregu- } \\
\text { lating the serotonin receptors by } \\
\text { the extract; } \\
\text { Changing the concentrations of } \\
\text { neurotransmitters in certain } \\
\text { regions of the brain; } \\
\text { Expressing genes controlling the } \\
\text { hypothalamic-pituitary-adrenal } \\
\text { axis; Antioxidant defense and } \\
\text { decreasing the inflammatory } \\
\text { factors IL- } 6 \text { and TNF-a }\end{array}$ & $\begin{array}{l}\text { Hypericin, } \\
\text { hyperforin, } \\
\text { and } \\
\text { isoquercetin }\end{array}$ & $\begin{array}{c}\text { Western } \\
\text { Europe, Asia, } \\
\text { and northern } \\
\text { Africa }\end{array}$ & Hydroalcoholic & $\begin{array}{c}{[42,43,44,} \\
44]\end{array}$ \\
\hline $\begin{array}{l}\text { Lavandula } \\
\text { angustifolia }\end{array}$ & Lamiaceae & FST & $\begin{array}{l}\text { Increasing serotonin and } \\
\text { gamma-aminobutyric acid, and } \\
\text { inhibiting release of acetylcho- } \\
\text { line; } \\
\text { Linalool through the receptors of } \\
\text { serotonergic and noradrenergic } \\
\text { systems. }\end{array}$ & $\begin{array}{c}\text { Linalool and } \\
\text { linaly1 } \\
\text { acetate }\end{array}$ & $\begin{array}{c}\text { Mediterranean } \\
\text { regions - } \\
\text { Spain, } \\
\text { France, Italy, } \\
\text { Croatia }\end{array}$ & Aqueous & {$[31,45,46]$} \\
\hline $\begin{array}{l}\text { Salvia offici- } \\
\text { nalis }\end{array}$ & Lamiaceae & TST, FST & The dopaminergic system & $\begin{array}{c}\text { Linalool and } \\
\text { apigenin }\end{array}$ & $\begin{array}{c}\text { Oaxaca, Mex- } \\
\text { ico }\end{array}$ & & $\begin{array}{c}{[45,46,47,} \\
48]\end{array}$ \\
\hline
\end{tabular}

\begin{tabular}{|c|c|c|c|c|c|c|c|}
\hline Name & Family & Model & Action mechanism(s) & $\begin{array}{l}\text { Main com- } \\
\text { pound(s) }\end{array}$ & $\begin{array}{c}\text { Place of } \\
\text { occurrence }\end{array}$ & $\begin{array}{c}\text { Type of used } \\
\text { extract }\end{array}$ & Reference \\
\hline $\begin{array}{l}\text { Rosmarinus } \\
\text { officinalis } \mathrm{L}\end{array}$ & Lamiaceae & TST, FST & $\begin{array}{l}\text { Monoaminergic system; } \\
\text { Regulating tyrosine hydroxylase } \\
\text { and pyruvate carboxylase } \\
\text { (genes involved in GABAergic, } \\
\text { serotonergic and dopaminergic } \\
\text { systems). }\end{array}$ & $\begin{array}{l}\text { Carnosicacid, } \\
\text { rosmarinic } \\
\text { acid, and lute- } \\
\text { olin } \\
\text { Ursolic acid }\end{array}$ & $\begin{array}{c}\text { Mediterranean } \\
\text { Regions }\end{array}$ & $\begin{array}{l}\text { Hexane, Ethy1 } \\
\text { acetate, Ethano- } \\
\text { lic, } \\
\text { Aqueous }\end{array}$ & {$[49,50,51]$} \\
\hline $\begin{array}{c}\text { Danggui } \\
\text { shaoyao San }\end{array}$ & & & $\begin{array}{l}\text { Modulating noradrenaline and } \\
\text { dopamine, and decreasing MDA } \\
\text { levels and increasing superoxide } \\
\text { dismutase (SOD) levels; } \\
\text { Producing effect on the seroton- } \\
\text { ergic system; } \\
\text { Releasing serotonin and norepi- } \\
\text { nephrine from synaptosome by } \\
\text { paeoniflorin }\end{array}$ & $\begin{array}{c}\text { albiflorin, } \\
\text { paeonflorin, } \\
\text { fluoric acid, } \\
\text { ligustrazine, } \\
\text { ligustilide and } \\
\text { ateraacetyllino } \\
\text { id. }\end{array}$ & Asia & & $\begin{array}{c}{[52,53,54,} \\
55,36]\end{array}$ \\
\hline Schinus molle & $\begin{array}{c}\text { Anacardi- } \\
\text { aceae }\end{array}$ & TST, FST & $\begin{array}{l}\text { Through serotonergic, dopa- } \\
\text { minergic, and noradrenergic } \\
\text { systems; } \\
\text { Through increasing noradrena- } \\
\text { line and serotonin in the synaptic } \\
\text { cleft. }\end{array}$ & $\begin{array}{l}\text { Flavonoid } \\
\text { compounds } \\
\text { including rutin }\end{array}$ & $\begin{array}{l}\text { South Amer- } \\
\text { ica }\end{array}$ & $\begin{array}{c}\text { Hexane, Ethano- } \\
\text { lic }\end{array}$ & {$[56,30]$} \\
\hline
\end{tabular}




\begin{tabular}{|c|c|c|c|c|c|c|c|}
\hline $\begin{array}{l}\text { Glycyrrhiza } \\
\text { glabra } \\
\text { (Liquorice) }\end{array}$ & $\begin{array}{l}\text { Leguminosae/ } \\
\text { Fabaceae }\end{array}$ & $\begin{array}{l}\text { TST, FST, } \\
\text { Locomotor } \\
\text { activity, } \\
\text { MAO } \\
\text { Inhibition } \\
\text { assay }\end{array}$ & $\begin{array}{l}\text { Inhibiting MOA and increasing } \\
\text { the concentrations of serotonin, } \\
\text { norepinephrine, and dopamine. }\end{array}$ & Glycyrrhizin & $\begin{array}{l}\text { Southem } \\
\text { Europe and } \\
\text { parts of Asia }\end{array}$ & $\begin{array}{l}\text { Aqueous, } \mathrm{Hy} \text { - } \\
\text { droalcoholic, } \\
\text { Ethanolic }\end{array}$ & {$[57,58,59]$} \\
\hline Crocus sativu & Iridaceae & FST & $\begin{array}{l}\text { Producing effect on the dopa- } \\
\text { minergic system and inhibiting } \\
\text { norepinephrine and safranal } \\
\text { reuptake on the serotonergic } \\
\text { system; } \\
\text { Increasing serotonin in the brain. }\end{array}$ & $\begin{array}{l}\text { Kaempferol, } \\
\text { Safranal, Cro- } \\
\text { cin }\end{array}$ & $\begin{array}{l}\text { Asia, Medi- } \\
\text { terranean } \\
\text { and Irano- } \\
\text { Turanian } \\
\text { region }\end{array}$ & $\begin{array}{l}\text { Aqueous, Etha- } \\
\text { nolic }\end{array}$ & {$[4,60]$} \\
\hline $\begin{array}{c}\text { Borage (Bor- } \\
\text { ago officinalis, } \\
\text { Echium } \\
\text { amoenum) }\end{array}$ & Boraginaceae & & $\begin{array}{l}\text { Inhibiting 5HT reuptake; Immu- } \\
\text { nomodulation }\end{array}$ & $\begin{array}{l}\text { Rosmarinic } \\
\text { acid } y \text {-linoleic } \\
\text { acid }\end{array}$ & $\begin{array}{l}\text { Europe, in the } \\
\text { Mediterranean } \\
\text { region, and } \\
\text { also in north- } \\
\text { em parts of } \\
\text { Iran }\end{array}$ & & {$[28,61]$} \\
\hline $\begin{array}{l}\text { Roseroot } \\
\text { (Rhodiola } \\
\text { rosea L.) }\end{array}$ & Crassulaceae & & $\begin{array}{l}\text { Inhibiting MOA-A; modulating } \\
\text { monoamine transmission; nor- } \\
\text { malizing serotonergic transmis- } \\
\text { sion }\end{array}$ & $\begin{array}{l}\text { Salidroside } \\
\text { Tyrosol } \\
\text { Rosavin }\end{array}$ & $\begin{array}{l}\text { Arctic regions } \\
\text { including } \\
\text { Alaska, } \\
\text { northeastem } \\
\text { Siberia and } \\
\text { northem parts } \\
\text { of Europe. }\end{array}$ & & [28] \\
\hline $\begin{array}{l}\text { Zingiber } \\
\text { officinale } \\
\text { (Ginger) }\end{array}$ & Zingiberaceae & $\begin{array}{l}\text { TST, FST, } \\
\text { Protein- } \\
\text { ligand } \\
\text { molecular } \\
\text { docking }\end{array}$ & Via binding to 5-HT1A receptor & $\begin{array}{l}\text { Gingerol, } \\
\text { Shoagol }\end{array}$ & $\begin{array}{l}\text { India, China, } \\
\text { Japan, Korea, } \\
\text { Vietnam, } \\
\text { Europe }\end{array}$ & Hydromethanolic & {$[62,63]$} \\
\hline
\end{tabular}

\begin{tabular}{|c|c|c|c|c|c|c|c|}
\hline Name & Family & Model & Action mechanism(s) & $\begin{array}{l}\text { Main com- } \\
\text { pound(s) }\end{array}$ & $\begin{array}{l}\text { Place of occur- } \\
\text { rence }\end{array}$ & $\begin{array}{c}\text { Type of used } \\
\text { extract }\end{array}$ & Reference \\
\hline $\begin{array}{c}\text { Piper } \\
\text { methysticum }\end{array}$ & Piperaceae & $\begin{array}{l}\text { MAO } \\
\text { Inhibition } \\
\text { assay }\end{array}$ & $\begin{array}{l}\text { Kavalactones inhibit MAO-B } \\
\text { Via } \\
\text { dopaminergic mechanism } \\
\text { and block the in vitro uptake } \\
\text { of noradrenalin }\end{array}$ & $\begin{array}{l}\text { Kawain, } \\
\text { dihydrokavain, } \\
\text { methysticin, } \\
\text { dihydromethys- } \\
\text { ticin and } \\
\text { yangonine }\end{array}$ & South Pacific & & {$[64,65]$} \\
\hline $\begin{array}{c}\text { Tagetes lucida } \\
\text { Cav. }\end{array}$ & Asteraceae & $\begin{array}{l}\text { FST, } \\
\text { Locomotor } \\
\text { activity }\end{array}$ & $\begin{array}{c}\text { Mediating effect by } \\
5-\mathrm{HT}_{\mathrm{iA}} \text { and } 5-\mathrm{HT}_{2 \mathrm{~A}} \text { receptors }\end{array}$ & $\begin{array}{l}\text { Quercetin gallic } \\
\text { acid, caffeic acid }\end{array}$ & $\begin{array}{l}\text { Mexico and } \\
\text { Central } \\
\text { America }\end{array}$ & $\begin{array}{l}\text { Aqueous, } \\
\text { Hexane, Di- } \\
\text { chloro- } \\
\text { methane, } \\
\text { Methanolic }\end{array}$ & {$[66,67]$} \\
\hline
\end{tabular}

*FST: forced swim test, * TST: tail suspension test, * CUMS: chronic unpredictable mild stress, *NMDA: N-methyl-D-aspart ate 


\section{CONCLUSION}

Recent pharmaceutical achievements for managing depression have not yet met with favorable clinical results. Some new and conventional drugs cause side effects. Medicinal plants provide many opportunities for the development of antidepressants. Antidepressant activities of plants are associated with various mechanisms including the HPA axis, monoamine neurotransmitters, and neurogenetic/neurotrophic factors, and their active ingredients play an important role in serotonergic, neuroadrenergic and dopaminergic systems. Hypericum, borage, and saffron exert their effects by inhibiting monoamine reuptake and roseroot and chamomile by inhibiting MOA. Hypericum produces an antidepressant effect by impacting serotonin receptors and lavender, chamomile and saffron by affecting GABAergic receptors [61]. However, the effects observed include a neurotrophic effect, such as activation of BDNF by saffron and ginseng, and neuroendocrine effects by hypericum, chamomile, and ginseng [61]. Saffron is also known as a postsynaptic NMDA receptor antagonist [61]. Studies have shown that hypericum extracts are the best registered natural treatments for mild to moderate depression. Its tolerance is good, but most important aspects are immunomodulation and pharmacokinetic and pharmacodynamic interactions. In several controlled clinical trials, saffron was shown to be more effective for mild to moderate depression than placebo and standard drugs. It is noteworthy that treatment with saffron is currently known to be the second leading herbal treatment for depressive symptoms $[25,28,70]$ and in comparison with hypericum extracts, it does not cause immune system problems. Experiments on other herbal remedies such as lavender, borage, chamomile and ginseng have demonstrated antidepressant effects, but it should be emphasized that they have not yet been definitely proven [28]. Growing evidence exists suggesting the presence of an association between the antioxidant defence system and oxidative stress with the development of neuropsychiatric disorders, including anxiety and depression. Anxiety and depression have been shown to be correlated with reduced antioxidant state or enhanced oxidative stress. The available antidepressants also mostly produce their therapeutic effects, in part, by increasing antioxidant levels. Antioxidants are able to remove free radicals by scavenging them, which would further protect neuronal damage induced by oxidative stress in the brain. This may help in the remission of anxiety or depression symptoms. Understanding the functional relationship between anxiety or depression and oxidative stress might pave the way for the discovery of novel targets and the preparation of new drugs for the treatment of neuro-psychiatric disorders [71]. It should be noted that since biochemical compounds from plants are metabolized in the liver, it is essential that they are studied in clinical trials before prescription use [25]. Therefore, the acceptance of herbal drugs for the treatment of mental disorders, including depression, requires standardization of herbal extracts and isolates, adequate scientific information on their safety and efficacy, the preservation of the diversity of medicinal plants, and appropriate laws and legal regulations that should be taken into consideration in developing anti-anxiety and antidepressant drugs.

\section{CONFLICT OF INTEREST}

The authors declare no conflict of interest, financial or otherwise. 


\section{REFERENCES}

[1] Rahmati B, Kiasalari Z, Roghani M, Khalili M, Ansari F. Antidepressant and anxiolytic activity of Lavandula officinalis aerial parts hydroalcoholic extract in scopolamine-treated rats. Pharm Biol 2017; 55(1): 958-65.

[2] Maria de Souza JM, Lira Ferrari GS, Bucalen Ferrari CK. Correlates of geriatric depression scale with perceived quality of life in an elderly population. Geriatr Persia 2018; 2: $\mathrm{e} 01$.

[3] Rajput MS, Sinha S, Mathur V, Agrawal P. Herbal antidepressants. IJPFR 2011; 1(1): 159-69.

[4] Noorbala AA, Akhondzadeh S, Tahmacebi-pour N, et al. Hydroalcoholic extract of Crocus sativus L. versus fluoxetine in the treatment of mild to moderate depression : A double-blind, randomized pilot trial. J Ethnopharmacol 2005; 28;97(2): 281-4.

[5] Dwyer AV, Whitten DL, Hawrelak JA. Herbal medicines, other than St. John's Wort, in the treatment of depression. Sci Rev Altern Med 2011; 1;16(1): 281-4.

[6] Tegegne MT, Mossie TB, Awoke AA, Assaye AM, Gebrie BT, Eshetu DA. Depression and anxiety disorder among epileptic people at Amanuel Specialized Mental Hospital, Addis Ababa, Ethiopia. BMC Psychiatry 2015; 15(1): 210.

[7] Rabiei Z, Rabie S. A review on antidepressant effect of medicinal plants. Bangladesh J Pharmacol 2017; 12(1): 1-11.

[8] Berton O, Nestler EJ. New approaches to antidepressant drug discovery: beyond monoamines. Nat Rev Neurosci 2006; 7(2): 137-51.

[9] Schulberg HC, Katon W, Simon GE, Rush AJ. Treating major depression in primary care practice: An update of the Agency for Health Care Policy and Research Practice Guidelines. Arch Gen Psychiatry 1998; 55(12): 1121-7.

[10] Drevets WC, Price ÆJL, Furey ML. Brain structural and functional abnormalities in mood disorders: implications for neurocircuitry models of depression 2008; 93-118.

[11] Ray WA, Griffin MR, Schaffner W, Baugh DK, Melton LJ III. Psychotropic drug use and the risk of hip fracture. N Engl J Med 1987; 316(7): 363-9.

[12] Roose SP, Glassman AH, Attia E, Woodring S. Comparative efficacy of selective serotonin reuptake inhibitors and tricyclics in the treatment of melancholia. Am J Psychiatry 1994; 151(12): 1735-9.

[13] Nestler EJ, Barrot M, DiLeone RJ, Eisch AJ, Gold SJ, Monteggia LM. Neurobiology of depression. Neuron 2002; 34(1): 13-25.

[14] Hindmarch I. Expanding the horizons of depression: beyond the monoamine hypothesis. Hum Psychopharmacol 2001; 16(3): 203-18. 
[15] Lee G, Bae H. Therapeutic effects of phytochemicals and medicinal herbs on depression. Bio Med Res Int 2017; 2017(6596241): 1- 11

[16] Barden N, Reul JM, Holsboer F. Do antidepressants stabilize mood through actions on the hypothalamic-pituitary-adrenocortical system? Trends Neurosci 1995; 18(1): 6-11.

[17] Pan Y, Kong LD, Li YC, Xia X, Kung HF, Jiang FX. Icariin from Epimedium brevicornum attenuates chronic mild stress-induced behavioral and neuroendocrinological alterations in male Wistar rats. Pharmacol Biochem Behav 2007; 87(1): 130-40.

[18] Plotsky PM, Owens MJ, Nemeroff CB. Psychoneuroendocrinology of depression. Hypothalamic-pituitary-adrenal axis. Psychiatr Clin North Am 1998; 21(2): 293-307.

[19] Menninger JA, Tabakoff B. Forskolin-stimulated platelet adenylyl cyclase activity is lower in persons with major depression. Biol Psychiatry 1997; 42(1): 30-8.

[20] Pandya CD, Howell KR, Pillai A. Antioxidants as potential therapeutics for neuropsychiatric disorders. Prog Neuropsychopharmacol Biol Psychiatry 2013; 46: 214-23.

[21] Maes M, Galecki P, Chang YS, Berk M. A review on the oxidative and nitrosative stress (O\&NS) pathways in major depression and their possible contribution to the (neuro)degenerative processes in that illness. Prog Neuropsychopharmacol Biol Psychiatry 2011; 35(3): 676-92.

[22] Liu $\mathrm{B}, \mathrm{Xu} \mathrm{C}, \mathrm{Wu} \mathrm{X}$, et al. Icariin exerts an antidepressant effect in an unpredictable chronic mild stress model of depression in rats and is associated with the regulation of hippocampal neuroinflammation. Neuroscience 2015; 294: 193-205.

[23] Xing H, Zhang K, Zhang R, et al. Determination of depression biomarkers in rat plasma by liquid chromatography-mass spectrometry for the study of the antidepressant effect of ZhiZi-HouPo decoction on rat model of chronic unpredictable mild stress. J Chromatogr B Analyt Technol Biomed Life Sci 2015; 988: 135-42.

[24] Ladep NG, Obindo TJ, Audu MD, Okeke EN, Malu AO. Depression in patients with irritable bowel syndrome in Jos, Nigeria. World J Gastroenterol 2006; 12(48): 7844-7.

[25] Sarris J, Panossian A, Schweitzer I, Stough C, Scholey A. Herbal medicine for depression, anxiety and insomnia: A review of psychopharmacology and clinical evidence. Eur Neuropsychopharmacol 2011; 21(12): 841-60.

[26] Fekadu N, Shibeshi W, Engidawork E. Major depressive disorder: pathophysiology and clinical management. J Depress Anxiety 2016; 6(255): 2167-1044.

[27] Novío S, Núñez MJ, Amigo G, Freire-Garabal M. Effects of fluoxetine on the oxidative status of peripheral blood leucocytes of restraint-stressed mice. Basic Clin Pharmacol Toxicol 2011; 109(5): 365-71. 
[28] Szafrański T. [Herbal remedies in depression--state of the art]. Psychiatr Pol 2014; 48(1): 59-73.

[29] Abdullaev FI, Espinosa-Aguirre JJ. Biomedical properties of saffron and its potential use in cancer therapy and chemoprevention trials. Cancer Detect Prev 2004; 28(6): 426-32.

[30] Machado DG, Bettio LE, Cunha MP, et al. Antidepressant-like effect of rutin isolated from the ethanolic extract from Schinus molle L. in mice: evidence for the involvement of the serotonergic and noradrenergic systems. Eur J Pharmacol 2008; 587(1-3): 163-8.

[31] Fajemiroye JO, da Silva DM, de Oliveira DR, Costa EA. Treatment of anxiety and depression: medicinal plants in retrospect. Fundam Clin Pharmacol 2016; 30(3): 198-215.

[32] Martins J, S B. Phytochemistry and pharmacology of antidepressant medicinal plants: A review. Biomed Pharmacother 2018; 104: 343-65.

[33] Cassani J, Ferreyra-Cruz OA, Dorantes-Barrón AM, Villaseñor RM, Arrieta-Baez D, Estrada-Reyes R. Antidepressant-like and toxicological effects of a standardized aqueous extract of Chrysactinia mexicana A. Gray (Asteraceae) in mice. J Ethnopharmacol 2015; 171: 295-306.

[34] Yu L, Zhang Y, Ma R, Bao L, Fang J, Yu T. Potent protection of ferulic acid against excitotoxic effects of maternal intragastric administration of monosodium glutamate at a late stage of pregnancy on developing mouse fetal brain. Eur Neuropsychopharmacol 2006; 16(3): 170-7.

[35] Takeda H, Tsuji M, Miyamoto J, Matsumiya T. Rosmarinic acid and caffeic acid reduce the defensive freezing behavior of mice exposed to conditioned fear stress. Psychopharmacology (Berl) 2002; 164(2): 233-5.

[36] Zeni AL, Zomkowski AD, Maraschin M, Rodrigues AL, Tasca CI. Ferulic acid exerts antidepressant-like effect in the tail suspension test in mice: evidence for the involvement of the serotonergic system. Eur J Pharmacol 2012; 679(1-3): 68-74.

[37] Yabe T, Hirahara H, Harada N, et al. Ferulic acid induces neural progenitor cell proliferation in vitro and in vivo. Neuroscience 2010; 165(2): 515-24.

[38] Jäger AK, Saaby L. Flavonoids and the CNS. Molecules 2011; 16(2): 1471-85.

[39] Saaby L, Rasmussen HB, Jäger AK. MAO-A inhibitory activity of quercetin from Calluna vulgaris (L.) Hull. J Ethnopharmacol 2009; 121(1): 178-81.

[40] Chen CR, Tan R, Qu WM, et al. Magnolol, a major bioactive constituent of the bark of Magnolia officinalis, exerts antiepileptic effects via the GABA/benzodiazepine receptor complex in mice. Br J Pharmacol 2011; 164(5): 1534-46. 
[41] Xu Q, Yi LT, Pan Y, et al. Antidepressant-like effects of the mixture of honokiol and magnolol from the barks of Magnolia officinalis in stressed rodents. Prog Neuropsychopharmacol Biol Psychiatry 2008; 32(3): 715-25.

[42] Bilia AR, Gallori S, Vincieri FFSt. St. John's wort and depression: efficacy, safety and tolerability-an update. Life Sci 2002; 70(26): 3077-96.

[43] Butterweck V, Schmidt M. St. John's wort: role of active compounds for its mechanism of action and efficacy. Wien Med Wochenschr 2007; 157(13-14): 356-61.

[44] Butterweck V. Mechanism of action of St John's wort in depression: what is known? CNS Drugs 2003; 17(8): 539-62.

[45] Seol GH, Shim HS, Kim PJ, et al. Antidepressant-like effect of Salvia sclarea is explained by modulation of dopamine activities in rats. J Ethnopharmacol 2010; 130(1): 18790.

[46] Herrera-Ruiz M, García-Beltrán Y, Mora S, et al. Antidepressant and anxiolytic effects of hydroalcoholic extract from Salvia elegans. J Ethnopharmacol 2006; 107(1): 53-8.

[47] Guzmán-Gutiérrez SL, Bonilla-Jaime H, Gómez-Cansino R, Reyes-Chilpa R. Linalool and $\beta$-pinene exert their antidepressant like activity through the monoaminergic pathway. Life Sci 2015; 128: 24-9.

[48] Avallone R, Zanoli P, Puia G, Kleinschnitz M, Schreier P, Baraldi M. Pharmacological profile of apigenin, a flavonoid isolated from Matricaria chamomilla. Biochem Pharmacol 2000; 59(11): 1387-94.

[49] Machado DG, Cunha MP, Neis VB, et al. Antidepressant-like effects of fractions, essential oil, carnosol and betulinic acid isolated from Rosmarinus officinalis L. Food Chem 2013; 136(2): 999-1005.

[50] Machado DG, Bettio LE, Cunha MP, et al. Antidepressant-like effect of the extract of Rosmarinus officinalis in mice: involvement of the monoaminergic system. Prog Neuropsychopharmacol Biol Psychiatry 2009; 33(4): 642-50.

[51] Sasaki K, El Omri A, Kondo S, Han J, Isoda H. Rosmarinus officinalis polyphenols produce anti-depressant like effect through monoaminergic and cholinergic functions modulation. Behav Brain Res 2013; 238: 86-94.

[52] Zhou K, Jia N, Jiang N, Wang F, Kou J. Beneficial effect of Danggui-Shaoyao-San, a traditional Chinese medicine, on drowsiness induced by chronic restraint stress. Neurosci Lett 2015; 597: 26-31.

[53] Kou J, Zhu D, Yan Y. Neuroprotective effects of the aqueous extract of the Chinese medicine Danggui-Shaoyao-san on aged mice. J Ethnopharmacol 2005; 97(2): 313-8. 
[54] Huang Z, Mao QQ, Zhong XM, et al. Mechanistic study on the antidepressant-like effect of danggui-shaoyao-san, a chinese herbal formula. Evid Based Complement Alternat Med 2012; 2012 (173565): 1- 7.

[55] Qiu F, Zhong X, Mao Q, Huang Z. The antidepressant-like effects of paeoniflorin in mouse models. Exp Ther Med 2013; 5(4): 1113-6.

[56] Cassani J, Dorantes-Barrón AM, Novales LM, Real GA, EstradaReyes R. Antidepressant-like effect of kaempferitrin isolated from Justicia spicigera Schltdl (Acanthaceae) in two behavior models in mice: evidence for the involvement of the serotonergic system. Molecules 2014; 19(12): 21442-61.

[57] Ofir R, Tamir S, Khatib S, Vaya J. Inhibition of serotonin re-uptake by licorice constituents. J Mol Neurosci 2003; 20(2): 135-40.

[58] Dhingra D, Sharma A. Antidepressant-like activity of Glycyrrhiza glabra L. in mouse models of immobility tests. Prog Neuropsychopharmacol Biol Psychiatry 2006; 30(3): 44954.

[59] Biswas UK, Choudhry B, Amrita K. Comparative evaluation of the antidepressant effects of ethanolic and queous extract of Glycyrrhiza Glabra in rats and mice. JGTPS 2012; 3(1): 585-601.

[60] Schmidt M, Betti G, Hensel A. Saffron in phytotherapy: pharmacology and clinical uses. Wien Med Wochenschr 2007; 157(13-14): 315-9.

[61] Berger F, Hensel A, Nieber K. Saffron extract and trans-crocetin inhibit glutamatergic synaptic transmission in rat cortical brain slices. Neuroscience 2011; 180: 238-47.

[62] Ittiyavirah SP, Paul M. In silico docking analysis of constituents of Zingiber officinale as antidepressant. J Pharmacognosy Phytother 2013; 5(6): 101-5.

[63] Singh RP, Jain R, Mishra R, Tiwari P. Antidepressant activity of hydroalcoholic extract of Zingiber officinale. IRJPAS 2012; 3(2): 149-51.

[64] Uebelhack R, Franke L, Schewe HJ. Inhibition of platelet MAO-B by kava pyroneenriched extract from Piper methysticum Forster (kava-kava). Pharmacopsychiatry 1998; 31(5): 187-92.

[65] Seitz U, Schüle A, Gleitz J. [3H]-monoamine uptake inhibition properties of kava pyrones. Planta Med 1997; 63(6): 548-9.

[66] Gabriela GC, Javier AA, Elisa VA, Gonzalo VP, Herlinda BJ. Antidepressant-like effect of Tagetes lucida Cav. extract in rats: involvement of the serotonergic system. Am J Chin Med 2012; 40(4): 753-68. 
[67] Gabriela GC, Javier AA, Elisa VA, Gonzalo VP, Herlinda BJ. Antidepressant-like effect of Tagetes lucida Cav. extract in rats: involvement of the serotonergic system. Am J Chin Med 2012; 40(4): 753-68.

[68] Low Dog T, Powell KL, Weisman SM. Critical evaluation of the safety of Cimicifuga racemosa in menopause symptom relief. Menopause. 2003; 10(4): 299-313.

[69] Kligler B. Black cohosh. Am Fam Physician 2003; 68(1): 114-6.

[70] Szafrański T. Zastosowanie szafranu (crocus sativus) w psychiatrii. Przegląd piśmiennictwa. Psychiatria, wydanie specjalne 2013. 1-13. http://www.psychiatraonline.pl/wpcontent/uploads/2017/06/PSYCHIATRA 1 eBOOK.pdf

[71] Xu Y, Wang C, Klabnik JJ, O’Donnell JM. Novel therapeutic targets in depression and anxiety: Antioxidants as a candidate treatment. Curr Neuropharmacol 2014; 12(2): 108-19.

[72] Rai D, Bhatia G, Palit G, Pal R, Singh S, Singh HK. Adaptogenic effect of Bacopa monniera (Brahmi). Pharmacol Biochem Behav 2003; 75(4): 823-30.

[73] Yuan X, Chapman RL, Wu Z. Analytical methods for heavy metals in herbal medicines. Phytochem Anal 2011; 22(3): 189-98.

[74] Malik J, Szakova J, Drabek O, Balik J, Kokoska L. Determination of certain micro and macroelements in plant stimulants and their infusions. Food Chem 2008; 111(2): 520-5.

[75] Brima EI. Toxic elements in different medicinal plants and the impact on human health. Int J Environ Res Public Health 2017; 14(10): 1209.

[76] Nasri H. Herbal drugs and new concepts on its use. J Prev Epidemiol 2016; 1(1): e01.

[77] Asgari A. Herbal medicines and kidney; friends or foes? J Nephropharmacol 2014; 3(1): $5-6$.

[78] Khodadadi S, Rafieian-Kopaei M. Herbs, health and hazards; a nephrology viewpoint on current concepts and new trends. Ann Res Antioxid 2016; 1(1): e05.

[79] Jafari T. Antioxidants; helpful or harmful? Ann Res Antioxid 2016; 1(2): e13.

[80] Fallah S, Rostaei M, Lorigooini Z, Surki AA. Chemical compositions of essential oil and antioxidant activity of dragonhead (Dracocephalum moldavica) in sole crop and dragonheadsoybean (Glycine max) intercropping system under organic manure and chemical fertilizers. Ind Crops Prod 2018; 115: 158-65.

[81] Amiri A, Amiri A. Antioxidants and disease prevention; an obscure association with great significance. Ann Res Antioxid 2017; 2(1): e02. 